Law in the Digital Age. 2021. Vol. 2, no. 3.

Вопросы права в цифровую эпоху. 2021. Т. 2. № 3.

Research article

УДК $341.1 / 8$

DOI: $10.17323 / 2713-2749.2021 .3 .126 .150$

\title{
International Law Regulation on Access to Health Technologies
}

\section{目 Vladislav S. Malichenko}

Institute of Legislation and Comparative Law under the Government of the Russian Federation, Moscow, Russia, vlad.malichenko@gmail.com

\section{睢目 Abstract}

Over the past decades, the number of system challenges in health protection has rapidly increased, impacting every country, regardless of the economic well-being level. The situation is mainly driven by socio-demographic shocks, geopolitical instability, as well as the lack of a systematic approach to the development of legal regulation of the health sector at the international and national level. Health technologies are fundamental to providing health care, social care, and responding to natural and deliberate emergencies. Access to healthcare technologies is regulated by various branches of international law, which determines the complexity of this process, as well as the need to form special international legal mechanisms to ensure systematic counteraction to threats in the field of health protection, including emergencies. This article presents analysis of the access to health technologies role in rethinking the concept of human security at the international level, as well as in the framework of national security strategies. The author consistently examines the main directions for the development of health technologies transfer regulation, including the protection of the IP rights, the formation of global partnerships in the field of procurement, as well as the harmonization of legal regulation within the framework of regional economic integration initiatives. Special attention in the article is paid to the analysis of the main international regulation for data transfer and access to scientific knowledge necessary for health technologies transfer, as well as the assessment of national regulation. Based on the conducted analysis, the author formulates proposals for improving the international legal mechanisms regulating access to health technologies. 


\section{O-1티 Keywords}

international law, security, right to health, health technologies, technology transfer, harmonization, access.

For citation: Malichenko V.S. International Law Regulation on Access to Health Technologies. Legal Issues in the Digital Age. 2021, no. 3, pp. 126-150. DOI: $10.17323 / 2713-2749.2021 .3 .126 .150$

From the moment the first International Sanitary Conferences were held in the early 19th century and the establishment of the International Office of Public Hygiene (OIHP) until the end of the first decades of the existence of the World Health Organization (WHO), the main focus of international cooperation and acts of international law in the field of health has been countering the spread of infectious diseases. Under the influence of technological advances that made it possible to curb the spread of infectious diseases, there was a shift in the priorities of international cooperation to issues related to non-communicable diseases (oncology, diabetes mellitus, cardiovascular diseases, hereinafter - NCDs) and the provision of universal health coverage.

NCD therapy involves the use of a variety of health technologies. For example, medical devices to control the course of the disease, drugs to curb the development of the disease, etc. The growing need for the use of health technologies forms a vicious circle, increasing the economic burden on health systems and, as a result, limiting access to health technologies, especially for vulnerable groups of the population, leading to disability, disability, which ultimately leads to a reduction in national income. The long-term socio-economic consequences for each state due to the spread of NCDs determined the attention to this problem not only on the part of WHO, but also became the basis for high-level meetings at the UN site in 2011, 2014 and 2018.

It should be noted that, despite significant advances in the development of antibiotics and an increase in the rate of vaccination, infectious diseases are becoming an increasing threat. In various regions of the world, more than 30 outbreaks of infectious diseases were recorded, which were an indicator of the imperfection of the legal mechanisms for controlling their spread, formed over the previous century [Mukherjee S., 2017: 459-467]. The main reasons for this situation, along with systematic problems in the activities of WHO and other international organizations, was the lack of comprehensive mechanisms for access to health technologies. 


\section{Defining term "health technologies"}

The term "technology" comes from the Greek "techne" which means a skill, art, craft, or method used to make a certain object, and "logos" which stands for "thought". Guided by the UN Secretary General's Report, technologies represent the main factor in ensuring human well-being and state development, allowing them to create new jobs, increase labor productivity, reduce the cost of goods and services, and expand the availability of medical and social assistance[Impact of rapid technological change on sustainable development, 2019: 17].

Despite the presence of the first mentions of the application of health technologies in the 7th century BC, to date, among the documents of international organizations and scientific research, a unified definition of the concept of health care technology has not been formulated. According to one of the first attempts to formulate a definition of this concept in Resolution WHO 60.20, health technology should be understood as the application of systematized knowledge and skills in the format of various medical applications (medicines, medical devices, etc.) aimed at improving the quality of life and solving global health problems.

It should be noted that after a decade, under the influence of rapid technological progress, the WHO definition no longer fully reflects the entire range of solutions actively implemented in the system of medical and social assistance. In particular, this thesis is confirmed in his speech by the WHO Director-General, who emphasizes the growing role of gene editing technologies, robotic surgery, 3-D printing, artificial intelligence (AI) for health systems. ${ }^{1}$ In addition, in the context of an increase in the rate of disability of the population and the regulation of social protection issues in the activities of the International Labour Organisation and other international organizations, it is necessary to mention assistive technologies aimed at improving the quality of life and the integration of persons with disabilities into social processes. [Rehabilitation in health systems, 2021: 35].

It is also necessary to mention the approaches to the definition of "health technology" at the national level, where this term is not enshrined in domestic law, but at the same time is presented in official documents prepared by authorized national institutions. Center for Healthcare Quality Assessment and Control of the Ministry of Health of the Ministry of

${ }^{1}$ WHO, WIPO, WTO Joint Technical Symposium on Cutting-Edge Health Technologies: Opportunities and Challenges. Available at: https://www.wipo.int/edocs/pubdocs/en/ wipo_pub_gc_20.pdf (accessed: 22.02.2021) 
Health of the Russian Federation has defined health technologies as any intervention that can be used to promote health, prevention, diagnosis, treatment of illness, rehabilitation of patients or provision of care, including drugs, medical devices, procedures and organizational systems. ${ }^{2}$ The National Information Center on Health Services Research \& Health Care Technology (NICHSR) of the United States defined health technologies as the practical application of knowledge to improve or maintain the health of humans and the population, formulating three ways of describing health technologies based on their physical nature (medical devices, software, pharmaceuticals). means, etc.), purposes of application (prevention, rehabilitation, diagnostics, etc.) and stages of implementation into practice (experimental, investigated, conceptual, etc.). ${ }^{3}$

\section{Current state of world health technologies market}

Under the influence of the technological process, accompanied by an increase in the life expectancy of the population and an increase in the need for medical and social assistance, healthcare technologies are one of the most dynamically developing world markets. By 2025, the pharmaceutical segment of the healthcare technology market alone will reach $\$ 1.6$ trillion, excluding the cost of vaccination against COVID-19, which will amount to $\$ 157$ billion. It should be noted, however, that the COVID-19 pandemic has led to an increase in the expected size of the pharmaceutical market by $\$ 88$ billion. The main sources of growth in the pharmaceutical market in the coming years will be drugs for the treatment of cancer and immunological diseases. In the next 5 years, 100 new drugs in the oncology segment are expected to be registered, with global costs reaching $\$ 260$ billion by $2025 .{ }^{4}$ Special attention should be paid to research in the development of gene-cell technologies, which marked the era of personalized medicine and suggests new approaches to the provi-

${ }^{2}$ Center for Healthcare Quality Assessment and Control of the Ministry of Health of the Russian Federation Available at: URL: https://rosmedex.ru/hta/ (accessed: 22.02.2021)

${ }^{3}$ National Information Center on Health Services Research and Health Care Technology (NICHSR). Available at: https://www.nlm.nih.gov/nichsr/hta101/ta10104.html (accessed: 22.02.2021)

${ }^{4}$ Global Medicine Spending and Usage Trends: Outlook to 2025. IQVIA 2021. Available at: https://www.iqvia.com/-/media/iqvia/pdfs/institute-reports/global-medicinespending-and-usage-trends-outlook-for-2025/iqvia-institute-global-medicines-and-usage-trends-to-2025-0421-forweb.pdf (accessed: 02.09.2021) 
sion of medical care. In 2020, research in the field of gene and cell products accounted for $12 \%$ of the total number of clinical trials. ${ }^{5}$ It should be noted that the predominant source of funding for such research is not pharmaceutical manufacturers, but government research institutes and venture funds. Thus, the volume of funding for research of gene and cell technologies by the US Government is more than 550 million US dollars annually. ${ }^{6}$ In 2020, under the influence of the COVID-19 pandemic, a rapid "digitalization" of the medical care system took place, which had a significant impact on the healthcare technology market, and also generated the need to improve the legal regulation of this area. To date, the number of various mobile applications in the healthcare sector has exceeded 350 thousand, of which 90 thousand were launched in 2020 [Digital Health Trends 2021: 2021]. The digital segment of healthcare technologies is characterized by significant investment attractiveness. In 2020, $\$ 24$ billion was invested in the development of digital solutions for the healthcare sector.

In the context of the rapid increase in the growth rates of investment in research and development, as well as the emergence of new health technologies, there is a growing need for the formation of sustainable international legal mechanisms that ensure equitable access to such technologies for all groups of the population.

\section{Access to health technologies on the agenda of international bodies}

Taking into account the complex nature of the regulation of using health technologies, each of the stages of which has a significant impact on the accessibility among the population, it should be noted that this issue is covered not only by WHO, but also by other UN specialized agencies, as well as by other participants in international relations in the field health protection.

For the first time, access to health technologies as an important element of health protection and the concept of human security was identified in the framework of the UNDP report "New dimensions of human security" 1994. However, the full importance of access to health technologies in the

${ }^{5}$ Available at: https://www.mckinsey.com/industries/life-sciences/our-insights/biopharma-portfolio-strategy-in-the-era-of-cell-and-gene-therapy (accessed: 02.09.2021)

${ }^{6}$ National Center for Advancing Translational Sciences. Past budgets. Available at: https://ncats.nih.gov/about/center/budget/past (accessed: 02.09.2021) 
international agenda was formulated in the framework of the Millennium Development Goals (MDGs) approved by the UN General Assembly in 2000. In particular, the achievement of three of the eight main goals, such as combating HIV / AIDS, malaria and other diseases, improving maternal health and reducing child mortality, ensuring the availability of essential medicines in developing countries, directly depend the availability of healthcare technologies. Further, within the framework of the Sustainable Development Goals (SDGs), which were also approved by the UNGA in 2015 as the successors of the MDGs, access to health technologies was identified as one of the objectives of SDG 3 "Ensuring healthy lifestyles and promoting well-being for all at all age".

Special attention in the international agenda is paid to ensuring control over the use of antibiotics both in medicine and in agriculture. The mandate to regulate this issue is mandated by WHO, FAO, OIE and UNEP. In particular, antibiotic resistance issues are considered within the framework of the Codex Alimentarius Commission, established by FAO together with WHO.

The implementation of measures to protect health is one of the nine main areas of social protection and involves ensuring the required level of health of the population through access to necessary health technologies, in particular - to basic medical services, as well as medicines and medical devices. In accordance with the Constitution of the organization, the ILO, along with WHO, plays an important role in the formation of international legal mechanisms that ensure access to health technologies. In particular, mention should be made of the Social Security (Minimum Standards) Convention, 1952, the Medical Care and Sickness Benefit Convention No. 130, 1969 and the Recommendation No. 202 on Social Protection Minimum Levels, 2012.

The WTO agreements are essential in regulating access to health technologies. The adoption of the TRIPS Agreement, which was aimed at simplifying access to technologies for the development of technological progress, as well as maintaining a balance of interests of producers and consumers, had a significant impact on the formation of a modern system for regulating access to healthcare technologies. The increase in the participation of the private sector in organizing the provision of medical and social assistance had a significant impact on the increase in the rate of trade in medical services. The GATS is the first and only universal agreement to regulate trade in services, including provisions for technology transfer for the benefit of developing countries. 


\section{The role of health technologies in achieving national priorities}

Over the past decades, issues of access to health technologies have gradually been integrated into the national priorities of each state as an important component of socio-economic well-being, the health of military personnel, as well as protection against non-military threats, serving as the basis for rethinking national security strategies. Every 5 years, starting from 2009, the President of the Russian Federation approves the National Security Strategy of the Russian Federation. Each of the three versions of the document addressed the issue of regulation of the transfer of health technologies to some extent. ${ }^{7}$

In particular, one of the priority tasks was determined to overcome technological dependence through the development of the domestic pharmaceutical industry to ensure guaranteed access of the population to medicines. In the latest version of the strategy, scientific and technological development is identified as one of the main priorities of national security, including the tasks of developing promising high technologies in the field of medicine and creating reserves of medical applications to counter various threats. ${ }^{8}$

The pandemic of coronavirus infection served as an incentive for the further development of the safety concept through the approval of the Federal Law "On the Biological Security of the Russian Federation" at the end of 2020, which formulated the tasks for the development, production and implementation of new technologies related to the use of pathogens, as well as the organization of scientific activities in the field of biological safety.

In the United States, health issues that have a direct impact on the security of the country have long been considered within the framework of separate strategies. Since 2009, the National Health Security Strategies (NHSS) have been developed by the Department of Health and Human Services to ensure timely responses to health emergencies. As amended by the strategy for 2015-2018 a separate goal is formulated to strengthen national capacities in the development, production and effective use of various medicinal products, including medicines. In the latest version of the

${ }^{7}$ Decree of the President of the Russian Federation of 12.05. 2009 №537 "Strategy of national security of the Russian Federation until 2020". National Security Strategy of the Russian Federation, approved by Presidential Decree of 31.12.2015 No. 683 // SPS Consultant Plus.

${ }^{8}$ Presidential Decree of 02.07.2021 No. 400 "On the National Security Strategy of the Russian Federation"// SPS Consultant Plus. 
Strategy 2019-2022 various aspects of access to health technologies are addressed [National Health Security Straegy 2019-2022: 2021]. In particular, the document emphasizes the need to ensure cybersecurity in the context of the spread of digital technologies in the medical care system, and also draws attention to the need to develop gene-cell technologies as the basis for the provision of personalized care. The document also pays special attention to the potential threat of the deliberate use of biological and chemical substances in the course of hostilities or terrorist activity.

Health issues figure in the Safety Strategies of regional organizations. Guided by Article 152 of the Treaty establishing the European Community, the activities of the state should complement the national policy aimed at improving public health, preventing the spread of diseases. In November 2009, the European Commission developed a working document on health security in the EU and internationally, summarizing the EU's priorities in addressing various threats, including ensuring the development of necessary health technologies. In July 2020. The European Commission has adopted the EU Security Strategy for the period 2020-2025. ${ }^{9}$ The document emphasizes the dependence of modern society on various technologies, which was vividly demonstrated in the context of the COVID-19 pandemic, and formulates the task of building capacity to quickly and timely confront health emergencies. The document also draws attention to the negative impact of the development of technology shortages on the development of criminal activity and significant consequences for the medical care system.

Thus, based on the analysis of the national security strategies of the leading world powers, a conclusion should be drawn about the final formation of the health sector as one of the most important components of state security and the determination of national goals to create the necessary conditions for access to health technologies.

\section{Human rights and access to health technologies}

Access to health technologies is one of the most important components of realizing the right to the highest attainable standard of health, as articulated in all universal and regional human rights instruments. In particular, in Art. 12 of the International Covenant on Economic, Social and Cultural Rights (ICESCR) defines the main components of the hu-

${ }^{9}$ Communication from the Commission to the European Parliament, The European Council, The Council, The European Economic and Social Committee and the Committee of the Regions on the EU Security Union Strategy COM/2020/605 final 
man right to health, including the need to ensure adequate health care, which implies access to health technologies. Access to health technology as a fundamental element of the human right to health was subsequently highlighted in General Comment 14, which enshrined four interrelated elements of this concept: availability, accessibility, acceptability, quality (AAAQs). ${ }^{10}$ The right to access to health technologies was included in the Declaration on the Right to Development, adopted by the UN General Assembly in 1986, which formulated the right of every person to participate in such economic, social, cultural and political development, in which it is possible to fully realize all human rights and freedoms, and established that states must ensure equality of opportunity in terms of access to basic resources in the field of health protection [Khabriev R.U., Abashidze A.Kh., Malichenko V.S., 2016: 16-22].

Judicial decisions must be consulted to address the practical aspects of the relationship between the right to health and access to health technologies. At the regional level, the decisions of the human rights courts have not directly addressed access to health technology as a component of the right to health, with the exception of a number of decisions of the InterAmerican Court of Human Rights. ${ }^{11}$ However, at the national level, there is more extensive jurisprudence recognizing the importance of access to health technologies in realizing the human right to health. This trend is largely due to an increase in the frequency of citizens' appeals to international courts due to limited access to healthcare technologies, especially in the developing regions of the world. In India, back in 1987 by a Supreme Court decision, health protection, including programs to ensure access to medicines at reasonable prices in accordance with the WHO List, was defined as part of the right to life as enshrined in the country's constitution. ${ }^{12}$ Subsequently, the Karnataka High Court formulated in its decision that restricting access to medicines under the WHO List is a violation of state policy in the field of drug provision. ${ }^{13}$ Subsequently, a series of decisions

${ }^{10}$ Committee on Economic, Social and Cultural Rights (CESCR), General Comment No. 14 on the right to the highest attainable standard of health, 11 August 2000, UN Doc. E/C.12/2000/4, para 17. Available at: http://www1.umn.edu/humanrts/gencomm/escgencom14.htm (accessed: 20.04.2019)

11 IACtHR, Caso Duque Vs Colombia. Excepciones Preliminares, Fondo, Reparaciones y Costas. Ruling of 26 February, 2016, Serie C, No 310, para. 174; Caso Cuscul Pivaral y otros vs Guatemala. Excepción Preliminar, Fondo, Reparaciones y Costas, Ruling of $23 \mathrm{Au}-$ gust, 2018, Serie C, No 359, para 108-114.

12 Vincent Panikurlangara v Union of India, 1987 AIR 990, Judgement of 03 March 1987.

${ }^{13}$ KS Gopinath v Union of India, Karnataka High Court, 21618/2002, Judgement of 12 November 2002, para 19. 
of the Supreme Court of India formulated the need to increase the availability of antiretroviral drugs for the treatment of HIV / AIDS. ${ }^{14}$ The Constitutional Court of South Africa, guided by the right to health, enshrined in the country's Constitution, found that the restrictions imposed by the government on access to antiretroviral drugs were unreasonable. ${ }^{15} \mathrm{In} \mathrm{Ni}$ geria, the Federal High Court, based on Art. 16 of the African Charter on Human and Peoples' Rights, which enshrines the human right to health, defined as violations of limiting the access of prisoners with HIV / AIDS to necessary medical care. ${ }^{16}$ The Constitutional Chamber of the Supreme Court of Costa Rica issued two judgments in 1997 making antiretroviral treatment mandatory for the social security system. ${ }^{17}$ Similarly, in deciding on access to health care, the Mexican Supreme Court included the provision of antiretroviral drugs on the national equivalent of the WHO List as an integral part of the constitutional right to health.

The right to access to health technologies, as well as the right to development, are inextricably linked with the right to access the achievements of scientific progress, as well as the right to participate in scientific progress, formulated in Art. 27 of the Universal Declaration of Human Rights (UDHR); Art. 15 para 1 (b) ICEXP, as well as in regional treaties, in particular in: Art. 13 para 2 of the American Declaration of the Rights and Duties of Man of 1948; Art. 14 par 1 c) of the Additional Protocol to the 1988 American Convention on Human Rights in the Field of Economic, Social and Cultural Rights ("San Salvador Protocol"); Art. 1 of Protocol No. 1 to the 1952 Convention for the Protection of Human Rights and Fundamental Freedoms (hereinafter - the European Convention on Human Rights). In practice, the implementation of the right to access the achievements of scientific progress involves finding a balance with the need to ensure the protection of intellectual property rights. According to the position of the CESCR, intellectual property is a social product with a corresponding function, which obliges states to form legal regimes of exclusive rights of developers to ensure a balance of compliance with the rights enshrined in the ICESCR.

${ }_{14}$ Sahara House v Union of India and others, Writ Petitions 535 of 1998, 512 of 1999, 61 of 2003 and 311 of 2003. Order of 2 December 2013.

${ }^{15}$ Minister of Health et al. v. Treatment Action Campaign et al, Constitutional Court of South Africa, Case CCT 8/02, Judgement of July, 2002, para 34-36 and Order of the Court.

${ }^{16}$ Festus Odefe and Others v Attorney-General and Others, Federal High Court of Nigeria, Port Hartcourt judicial division, Suit FHC/PH/CS/680/2003, Decision of 23 February 2004.

17 Luis Guillermo Murillo Rodríguez et al v Caja Costarricense de Seguro Social, Sala Constitucional, Decisión 6096-97, 1997; William García Álvarez v Caja Costarricense de Seguro Social, Decisión 5934-97, 1997. 


\section{Development of legal regulation of access to health technologies}

As noted earlier, the circulation of health technologies is a complex process, each stage of which is governed by acts of a universal and regional nature that shape various branches of international law, expanding or restricting access to health technologies.

Ensuring the affordability of healthcare technologies is primarily associated with international and national regulations governing the protection of the exclusive rights of healthcare technology developers. The institution of patent protection has undoubtedly become the main systematic development of innovative activity, which is especially noticeable in the segment of healthcare technologies, but at the same time, under certain circumstances, it can be a significant barrier limiting the realization of the human right to health.

However, patent protection, being the most discussed problem in scientific publications in recent years, is only the tip of the iceberg. Health emergencies have highlighted the problem of lack of necessary technology at the time of the spread of disease. Timely development of health technologies is possible through the creation of the necessary mechanisms for the transfer of scientific data and biological materials, as well as adequate investment in research activities. Another barrier to access to health technologies is the lack of essential medical supplies. Countering the shortage is possible by creating special planning programs and organizing the procurement of vital drugs and medical devices, both at the international and regional levels. An important way to counter the deficit is to create the necessary production capacity to meet the needs of a particular region.

\section{Legal mechanisms for the transfer of health technologies}

Technology transfer regulation has a special place in international law, given that 48 of the 169 targets identified under the SDG are directly related to access to technology. In particular, ensuring access to technology is highlighted as a separate area under SDG 17 to expand tripartite, regional and international cooperation in the fields of science, technology and innovation between existing mechanisms at the UN level, as well as through the global mechanism for promoting technology transfer. ${ }^{18}$

${ }_{18}$ UN General Assembly Resolution A / RES / 70/1. 2015. Transforming Our World: The 2030 Agenda for Sustainable Development. 
Today, there are practically no acts of a universal nature that contribute to the systematic transfer of health technologies. The only international legal mechanisms that allow the transfer of health technology directly are compulsory and voluntary licensing, which are separately considered later in the article. Some success can be seen in the development of mechanisms to facilitate the transfer of scientific data required for research and development of health technologies. In particular, the timely exchange of pathogens and the sharing of research results are essential in the development of various health technologies to respond to infectious pandemics. In particular, the 1992 Convention on Biological Diversity emphasizes the importance of access to genetic resources and technologies in meeting health needs. It is important to note that the provisions of the Convention apply to viruses containing nucleic acids in their structure, which should be classified as genetic material. Access to selected viruses is essential in developing scientific capacity and the timely development of health technologies needed to respond to infectious pandemics.

Another international communication mechanism for health technology development is the Pandemic Influenza Preparedness Framework, which recognizes the principle of sovereign rights of states over their biological resources and defines the main goal of sharing influenza viruses with pandemic potential, as well as scientific data and developments. A unique aspect of the Facility is the involvement of the private sector, through two types of "standard material transfer agreements" that ensure the transfer of virus samples to developers, as well as the reciprocal obligations of the manufacturer in the form of specific amounts of vaccines and other benefits provided. Within the framework of the mechanism, three categories of parties to the agreement are distinguished: manufacturers of vaccines and antiviral drugs (category A), manufacturers of medical devices (category B), research institute (category B). Today, 73 agreements with research institutes are in force, within the framework of which it is envisaged to conduct educational events for the creation of state research centers, and to license the production of developed technologies. 14 existing agreements with pharmaceutical manufacturers ensured that 420 million doses of vaccines would be provided to countries in need in the event of a pandemic, as well as 10 million courses of antiviral drugs. In addition, under two agreements with manufacturers of medical devices, 250 thousand diagnostic kits and 25 million disposable syringes have been reserved. ${ }^{19}$

19 Pandemic Influenza Preparedness Framework: annual progress report, 1 January 31 December 2020. Geneva, 2021. 
At the national level, a more systemic, albeit not unified, approach has emerged to the creation of regulatory mechanisms that create favorable conditions for the production of necessary health technologies and the formation of scientific potential in this area. The turning point in the development of the health technology transfer system in the United States was the adoption of the Stevenson-Wydler Act of $1980^{20}$, which established a mechanism for the transfer of technology from government agencies to the private sector under the Bayh-Dole Act of 1980, which allowed universities, small businesses, and non-profit organizations to patent and license technologies directly developed through federal research or cooperation agreements. ${ }^{21}$

In the Russian Federation the formation of regulatory mechanisms to facilitate the development of the transfer of healthcare technologies began relatively recently and was largely aimed at providing financial support and other economic preferences for domestic enterprises in the medical and pharmaceutical industries, as well as foreign companies planning to transfer technology to Russia. The main document for the development of national potential in the development and production of health technologies was the "State Program for the Development of the Medical and Pharmaceutical Industry 2013-2020", which defined targeted measures to ensure the development and production of medicines and medical devices in the country. Another mechanism for the development of the transfer of technologies for their production on the territory of the Russian Federation was the Special Investment Agreement (SPIK) provided for by the Federal Law of December 31, 2014 No. 488-FZ (as amended on December 31,2017 " On industrial policy in the Russian Federation". The SPIK is concluded for technologies from 15 industries, including the medical and pharmaceutical sector, included in the list of modern technologies, formed on the basis of the rules approved by the Decree of the Government of the Russian Federation No. 319 of March 21, 2020. The SPIK is concluded for a period not exceeding 10 years, and provides for a number of preferences from the state in case of production on the territory of the Russian Federation.

\section{Legal regulation of researches}

Research is the backbone of access to health technology. Adequate legal regulation of research activities, together with the necessary volumes of in-

\footnotetext{
${ }^{20}$ Stevenson-Wydler Act of 1980. Public Law, 96-480.

${ }^{21}$ The Bayh-Dole Act of 1980. Public Law, 96, 517.
} 
vestments, make it possible to create favorable conditions for the development of the necessary health technologies. One of the main conditions for the allocation of financing from companies is the attractiveness of the research area in the context of the return on investment. Traditionally, fundamental research is funded by the state, while applied research aimed at developing a specific technology (drug, medical device, etc.) is supported by private companies [Schweitzer S.O., Lu Z.J., 2018:39]. At the same time, the lack of sufficient government funding is compensated by the provision of various kinds of preferences to manufacturers.

The cost of research and development is constantly increasing. It cost about $\$ 1.3$ billion to market a drug in 2010, up from 138 million in 1975 [DiMasi J.A., Grabowski H.G., 2007: 469-479]; [DiMasi J.A.,, Grabowski H.G., 2003: 151-185]. ${ }^{22}$ Thus, over the past 35 years, research spending has increased by almost 10 times. The ratio of R\&D investment to pharmaceutical sales is five times that of the average US manufacturing company. ${ }^{23}$ The growth rate of the pharmaceutical market has undoubtedly contributed to the increase in research and development expenditures. To date, the number of clinical trials of drugs has reached an all-time high. More than 850 clinical trials are underway for COVID-19 vaccines and drugs alone. Total spending on drug research in 2020 was $\$ 198$ billion. ${ }^{24}$ At the same time, the volume of investments of the 11 largest pharmaceutical manufacturers reaches $\$ 86.3$ billion. $^{25}$

The high cost of medicines and other health technologies is in most cases justified by high investment in research activities. At the same time, often the bulk of funding falls on the early stages of research, which are carried out at the expense of state budgets in research organizations and subsequently transferred under certain conditions to private companies. As noted in the report of the Lancet Commission on Access to Essential Medicines for Universal Health Coverage, there is a need for national procedures that take into account public investment in health technology pricing [Wirtz V.J., Hogerzeil H.V., Gray A.L., 2017: 403-476].

${ }^{22}$ Available at: https://www.ghtcoalition.org/pdf/Saving-lives-and-creating-impactsummary.pdf (accessed: 19.09.2021)

${ }^{23}$ USCBO. Research and Development in the Pharmaceutical Industry. Congress of the United States, Congressional Budget Office. 2006. P. 65. Available at: https://www.cbo. gov/sites/default/files/109th-congress-2005-2006/reports/10-02-drugr-d.pdf (accessed: 29.08.2021)

${ }^{24}$ Available at: https://www.statista.com/statistics/309466/global-r-and-d-expenditure-for-pharmaceuticals/ (accessed: 29.08.2021)

${ }_{25}$ Available at: https://www.evaluate.com/vantage/articles/data-insights/other-data/ roche-remains-big-pharmas-biggest-rd-spender (accessed: 29.08.2021) 
Investment in the development of certain health technologies is grossly disproportionate. For example, the number of clinical studies in the field of oncology significantly exceeds the number of studies on the treatment of infectious diseases, which are common only in a limited number of countries in the world. The mechanisms of patent protection and data exclusivity established in industrialized countries in general, as well as other preferences, facilitate drug development without significant additional therapeutic benefits in areas with a large number of different treatment options or me too drugs, thereby limiting access to the necessary drugs in developed countries due to the high cost, as well as the lack of developed technologies for the treatment of diseases in developing countries.

\section{The role of intellectual property rights protection mechanisms}

Among the main factors influencing access to health technologies, special attention in international organizations and scientific research is paid to mechanisms for protecting the exclusive rights of developers to the results of intellectual activity. Registration of a patent provides for the full disclosure of the data of their inventions, allowing other subjects to use this technology in the future. In this case, the applicant receives exclusive rights to the invention, valid for a certain period of time [Abashidze A.Kh., Malichenko V.S., 2019: 62-79].

To date, patent protection is undoubtedly the basic legal instrument that allows its owners to single-handedly set the price of technology to ensure reimbursement of research and development costs. It is not possible to predict the required volume of investments in development at the initial stages due to the fact that in practice only a few initially selected molecules of drugs or prototypes of medical devices demonstrate the indicators required for registration.

Almost until the end of the 20th century, approaches to ensuring patent protection for healthcare technologies differed significantly from state to state. By the beginning of the Uruguay Round of trade negotiations in 1986, 49 out of 98 states parties to the Paris Convention of 1883 excluded pharmaceutical products from the list of objects subject to patent protection, 10 - pharmaceutical technological processes, and 22 - chemical technological processes [Dutfield G., 2003: 304]. Countries differed in terms of the duration of patent protection and / or the presence of other restrictions on the rights of patent holders. Such exceptions were wide- 
spread in Western countries as well. For example, pharmaceutical patents were not granted in the following European countries: France (until 1960), Switzerland (until 1977), Italy (until 1978), Sweden (until 1978), and Spain (until 1992).

The Agreement on Trade Related Aspects of Intellectual Property Rights (TRIPS) was the first multilateral treaty to enshrine the main criteria for patentability and approve uniform standards for granting patents for various products, including health technologies. The Agreement also states that the term of the protection granted is 20 years from the date of filing of the application. The TRIPS Agreement provided for a number of transition periods, including the introduction of patenting, to ensure the phased implementation of commitments.

It is generally agreed that in most studies patent protection is a major factor in driving high prices for medicines and other medical uses. At the same time, the price level can differ significantly depending on the region of the world, which is increasingly being discussed by the governments of various countries, as well as international organizations. In particular, the sharp rise in the price of patented drugs in the United States was the subject of an investigation by the House of Representatives Oversight and Reform Committee in 2020. ${ }^{26}$

The coronavirus pandemic has exacerbated the long-debated possibility of voluntarily waiving patent protection for selected health technologies in emergencies. So, in October 2020, India and South Africa proposed to the WTO to abandon patent protection for vaccines in the context of a pandemic to ensure their international availability. ${ }^{27}$ This proposal was supported by 100 countries from two key WTO groups: the African group and the group of least developed countries, but was rejected by the EU, the United States and a number of industrialized countries.

In the context of the discussion of the role of patent protection, the criteria of patentability are an important issue, especially in the case of

${ }^{26}$ The US House Committee on Oversight and Reform. Investigation of Skyrocketing Prescription Drug Prices. Available at: https://oversight.house.gov/investigations/investigation-of-skyrocketing-prescription-drug-prices (accessed: 29.08.2021)

The US House Committee on Oversight and Reform. Oversight Committee Announces Major Hearings with Drug Company CEOs after 18-Month Investigation. Available at: https://oversight.house.gov/news/pressreleases/oversight-committee-announces-majorhear (accessed: 29.08.2021)

27 World Trade Organization. Waiver from certain provisions of the TRIPS agreement for the prevention, containment, and treatment of COVID-19: communication from India and South Africa IP/C/W/669, 2020. Available at: https://docs.wto.org/dol2fe/Pages/SS/ directdoc.aspx?filename=q:/IP/C/W669.pdf\&Open=True (accessed: 29.08.2021) 
the use of artificial intelligence technologies in the development of health technologies. In 1988, the UK became the first country to enact the Copyright, Industrial Designs and Patents Act 1998 (CDPA), which contains provisions for artificial intelligence works. Since 1973, the US Copyright Office has enforced a human authorship requirement that prohibits registration of "works created by a machine or a simple mechanical process that works randomly or automatically without any creative input or intervention from a human author."

None of the jurisdictions have laws or regulations regarding artificial intelligence inventions. The growing role of artificial intelligence in the development of various technologies is causing significant debate among academia and industry, especially with regard to the development of health technologies. ${ }^{28}$ In such conditions, there is a high probability of revising the criterion of patentability, as well as signs of violation of the exclusive rights of technology developers.

Along with patent protection, an increasing impact on the availability of healthcare technologies is exerted by mechanisms for protecting data from clinical trials, limiting the possibility of their use by other manufacturers to register similar technologies for a period specified by law. In the United States, data exclusivity regulation was introduced under the Drug Price Competition and Patent Extension Act of 1984, also known as the Hatch-Waxman Act, which provided 5 years of protection for low molecular weight chemicals, 3 years of protection for registrations of new indications of registered drugs. drugs, 4 years for biological drugs.

At almost the same time, Directive 87/21 / EEC of 1987 was adopted in the EU, which established a 6-year period for protecting the exclusivity of data used in newly registered medicinal products. In addition, EU member states were empowered to extend the data exclusivity protection period up to 10 years if there is a substantial need from the healthcare system. In 2004 , as a result of the harmonization of regulation throughout the EU, a unified data exclusivity protection regime was formed, which implies the provision of 8 years of protection for all drugs, an additional two years within which it is possible to register generic drugs without putting them into civil circulation, as well as an additional year upon registration a new indication for use. ${ }^{29}$

${ }^{28}$ Intelligent drug discovery Powered by AI, Deloitte, 2019. Available at: https://www2. deloitte.com/us/en/insights/industry/life-sciences/artificial-intelligence-biopharma-intelligent-drug-discovery.html (accessed: 02.09.2021)

${ }^{29}$ Directive 2004/27/EC on the Community code relating to medicinal products for human use. OJ L136/34. 
It is important to note that abandoning patent protection will not allow sustainable access to health technologies, but rather reduce the pace of research and development. It is necessary to take into account the existing global inequality in production capacity. If a certain country seeking compulsory licensing does not find a manufacturer with the ability and willingness to carry out the required production, the issue of authorization remains controversial. The economic problems of the least developed countries, where the presence of local pharmaceutical manufacturers is limited, may impede wider access to essential medicines in emergencies, despite the increased flexibility of the TRIPS Agreement.

\section{Application of the "flexible mechanisms" of the TRIPS Agreement}

The restriction of access to healthcare technologies due to their high cost determined the advisability of using special mechanisms to ensure the lawful production of more affordable analogues. The TRIPS Agreement contains a number of provisions that can be used by member countries in certain circumstances to overcome patent protection and, in particular, to expand access to medicines. These provisions, commonly referred to as the "flexible provisions of the TRIPS Agreement in the field of public health", provide for a number of important mechanisms and guarantees that countries can use to reduce prices and expand access to patented and non-patented health technologies.

One of these mechanisms is compulsory licensing, which has been used as a tool to ensure access to innovation in various regions of the world for more than a century. The introduction of compulsory licensing was discussed in the British Monopoly Act of 1623, the first US patent law of 1790, and the patent regulation of Saxony (Germany) in 1853 [Chien C., 2003: 853-907]. Compulsory licensing was actively used in Canada from 1923 until joining the North American Free Trade Agreement (NAFTA). In the period from 1979 to 1985, United States and other developed economies around the world have repeatedly attempted to initiate a revision of the Paris Convention to limit the possibility of compulsory licensing.

The US Trade Mission defines compulsory licensing "as a permit granted under special conditions to third parties to use patented products without the permission of the patent owner". A compulsory license may be issued to one or more persons to use a patented product without the permission of the patentee, provided that sufficient monetary compensation is paid to the patentee. 
TRIPS Agreement Art. 31 does not provide for any restrictions on the grounds on which compulsory licenses can be issued, provided that the procedure for their issuance meets the established minimum requirements. At the same time, at the national level, additional requirements may be provided for the application of compulsory licensing. For example, in Ireland, compulsory licenses for any reason can only be granted 3 years after the grant of the patent. This is usually not a significant practical limitation on the use of compulsory licenses, given that it takes much longer to obtain regulatory approval for the use of the technology.

The COVID-19 pandemic has provided a systemic rethinking of the use of compulsory licensing in various regions of the world. For example, in 2020, Canada passed laws to facilitate the accelerated issuance of compulsory licenses. Germany has passed the Infectious Disease Prevention and Control Act, empowering the Ministry of Health to grant compulsory licenses under section 13 of the Patent Act in the event of a national epidemic being declared. Similar measures were also taken in France by the Emergency Law No. 2020-290 of March 23, 2020 to combat the COVID-19 epidemic, which introduced a new article L.3131-15 in the Public Health Code authorizing the Prime Minister to act in order to ensure public health, including the provision of public use of patented inventions.

In the Russian Federation, the use of compulsory licensing in the interests of defense and security with the payment of commensurate compensation to the patent holder is permitted by Art. 1360 of the Civil Code of the Russian Federation. It should be noted, however, that until April 2021, the article did not provide for any special provisions for medicinal products. For the first time, guided by the provisions of the aforementioned article, in December 2020, by the order of the Government of the Russian Federation, the domestic manufacturer was granted the right to manufacture a drug for the treatment of COVID-19. Federal Law No. 107-FZ of April 30, 2021 amended Art. 1360, which supplemented the grounds for granting a compulsory license with the purpose of ensuring the protection of the life and health of citizens.

When discussing the issue of compulsory licensing, it is necessary to mention the possibility of the patent owner voluntarily granting the right to use the patent to third parties on the basis of licensing agreements that allow a third party to use intellectual property with payment of royalties (licensing fees), in relation to a certain area of use, in a certain territory and for a certain period, which may coincide with the term of the patent. The development of the trend towards the transfer of rights to manufacture drugs, in particular for the treatment of HIV / AIDS, under license agree- 
ments to manufacturers of generic drugs has stimulated the creation of a patent pool of drugs [Bermudez H., 2010: 37].

As part of the negotiation process, the patent pool reaches an agreement with patent holders on the possibility of granting the corresponding rights for the production of medicines for the treatment of HIV, hepatitis and tuberculosis to other manufacturers on a non-exclusive and non-discriminatory basis for distribution in countries with a low level of economic development. At the same time, patent holders receive a license fee for the granted access to intellectual property.

\section{Global partnerships for the procurement of health technologies}

Differing levels of development of health systems, as well as disproportionate levels of well-being in different regions of the world, create barriers to access to life-saving health technologies. This determined the need for interaction between international organizations, non-governmental bodies, transnational corporations, etc., in relation to providing access to some of the most popular healthcare technologies. As an example, first of all, it is necessary to mention various global initiatives for the procurement of funds for the prevention and treatment of HIV / AIDS, tuberculosis and malaria in the developing regions of the world, such as UNITAID, Gates Foundation, Global Alliance for Vaccines and Immunization, The Global Fund to Fight AIDS, Tuberculosis and Malaria. The COVID-19 pandemic has heightened the need to organize global initiatives to ensure access to health technologies. The rapid development of the deficit of various health technologies has determined the need for the formation of global initiatives to support the most affected countries in the world. In 2020, WHO launched the Accelerating Access to COVID-19 (ACT) Initiative in four pillars: access to diagnostics, treatment, vaccines and health systems strengthening. In particular, the goal of expanding access to vaccines, led by WHO and the GAVI Alliance, envisages the creation of the necessary production capacity and an equitable distribution of 2 billion doses of vaccines by the end of 2021 .

An analysis of the specifics of access to health technologies demonstrated the leading positions of various global initiatives that are not traditional subjects of international law, but have comparable political influence with WHO. The increasing role of global partnerships in international relations rightly raises the question of revising the concept of legal personality in international law, as well as determining the possibility of bringing these 
partnerships to legal responsibility in the event of harm to the health and well-being of the population of individual states.

Bilateral pre-purchase agreements between manufacturers and the EU have had a significant impact on the availability of vaccines. The idea of creating a single mechanism for the procurement of healthcare technologies began to be discussed at the EU platform since the outbreak of the SARS virus and avian influenza. Decision No. 1082/2013 / EU "On Serious Cross-Border Threats to Health" formed the legal basis for the adoption in April 2014 by the European Commission of the Joint Procurement Agreement for the supply of various medical products in order to counter crossborder threats to health.

The developed Vaccine Strategy, adopted by the European Commission in June 2020, emphasizes the need for a centralized procurement process for vaccines. As part of supporting the development and manufacture of vaccines, the Commission enters into agreements with individual manufacturers on behalf of Member States. In exchange for the right to buy a certain number of doses of vaccine at a given time and price, a portion of the initial cost to the vaccine manufacturer will be funded from the Emergency Support Instrument (ESI). In parallel, EU legislation provides for other mechanisms to ensure a systematic response to threats and challenges in the field of health protection. Within the framework of the special "rescEU" procedure provided for by the EU civil protection mechanism, the European Commission's Directorate General for Civil Protection and Humanitarian Aid is forming a special reserve of vital medical products to counter the development of shortages due to the coronavirus pandemic.

The EU experience is indicative in the context of the formation of a single pharmaceutical market and the market for medical devices of the EAEU countries and the prospects for the formation of mechanisms for the centralized procurement of certain healthcare technologies in certain situations that pose a threat to the security of states.

\section{The importance of harmonization processes in ensuring safety and quality of healthcare technologies}

Today, due to the processes of globalization, the main stages of the circulation of healthcare technologies, including the development, production, transportation, circulation, are no longer carried out within one state, suggesting the involvement of different regions of the world in each stage. However, differences in the level of socio-economic well-being of states 
have a significant impact, both on the organizational and technical potential of the necessary control and supervisory functions, and on the level of development of the system of legal regulation of the circulation of health technologies.

Harmonization of regulation of the healthcare technologies circulation, implemented at the regional level, is primarily aimed at introducing a unified regulatory framework that allows ensuring the required standard of safety and quality. Most of the initiatives to harmonize regulation of the circulation of health technologies are implemented on the basis of regional economic integration processes, among which the European Union, the Eurasian Economic Union, and the African Union should be mentioned.

The regulation of the circulation of medicinal products in the EU is carried out on the basis of Directives and Regulations. The regulation primarily acts as a tool for the unification of law. The EU is a vivid example of not only harmonization of regulation in the field of health protection and, in particular, the circulation of health technologies throughout the space of the member states, but also the formation of supranational structures responsible for the coordination and implementation of these processes. Such a structure is the European Medicines Agency (EMA), established by Regulation (EC) No 726/2004 of the European Parliament and of the Council of March 31, 2004.

The example of the European Union clearly demonstrates the effectiveness of the supranational system of regulation of the most important stages of the health technologies circulation, and this approach allows to ensure control over the safety and availability of these technologies. The EAEU acts primarily as an international organization for regional economic integration, affecting such areas of regulation as economics, science, education, culture, ecology and trade. On January 1, 2021, the provisions governing the activities of the single pharmaceutical market of the EAEU countries came into force, in many respects repeating the principle of convergence of regulation of healthcare technologies that has emerged within the EU. Undoubtedly, the creation of single markets is primarily aimed at the maximum convergence of the regulation of the medical and pharmaceutical industries of the EAEU member states with the European Union.

Harmonization processes gradually began to develop in the African region as well. In January 2005, the New Partnership for Africa's Development (NEPAD) outlined an Africa Pharmaceutical Development Plan to expand access to safe, quality and effective health technologies. Subsequently, in 2009, NEPAD also launched the African Medicines Regulatory Harmonization (AMRH) Initiative. On the basis of the initiative, a draft 
African Union Model Law on the Regulation of Medical Products was developed in January 2016 and subsequently approved by the Health, Labor and Social Affairs Committee of the African Union's Pan-African Parliament. The document was aimed at harmonizing the regulation of various health technologies. The African Union Assembly, at its 32nd Ordinary Session in Addis Ababa in 2019, adopted an agreement establishing the African Medicines Agency (AMA), which will expand to 55 countries in the African region, forming 8 different regional economic associations. The treaty will enter into force upon ratification by 15 countries of the African region. The current multi-country vaccine testing model, the African Vaccine Regulatory Forum (AVAREF), is expected to be expanded through the work of the African Agency.

\section{Conclusion}

The increase in the frequency of emergencies in the field of health has shown that, despite the significant technological progress achieved, which makes it possible to provide treatment for deadly diseases, as well as rethinking the importance of health technologies in achieving international development goals, ensuring national security and the socio-economic well-being of states, there is currently no systematic approach to regulating the transfer of health technologies at the global level. Of paramount importance for ensuring timely access to healthcare technologies is the formation of a legal mechanism that ensures an increase in the pace of development of technologies necessary to counter life-threatening diseases. Among such measures, it is necessary to mention the provision of sustainable funding, the transfer of research data between states, as well as access to biological materials necessary for development. The positive experience in the formation of patent pools determines the need for the systematic use of voluntary licensing of healthcare technologies for the production of medical products in the required volumes, as well as the development of local production facilities in the developing regions of the world. In the context of the formation of a single market for pharmaceuticals and medical devices in the EAEU countries, the experience of the European and African regions with regard to the creation of a supranational regulatory body regulating the circulation of health technologies is useful. The creation within the EAEU of a similar organization with supranational powers to regulate the circulation of health technologies will help to ensure control of safety, quality and efficiency. Solving the set tasks will require the systematic involvement of international organizations and the application of various branches of inter- 
national law to form acts of a universal nature aimed at ensuring sustainable access to the necessary healthcare technologies.

\section{I目 References}

1. Abashidze A., Malichenko V. (2019) Compulsory licensing mechanism under international and national law. Vestnik RUDN. Yuridicheskiye nau$k i=$ Herald of Russian University of People's Friendship, vol. 23, no. 1, pp. 62-79. (In Russ.).

2. Bermudez J., Hoen E.T. (2010) The UNITAID patent pool initiative: bringing patents together for the common good. The Open AIDS journal, no. 4 , p. 37.

3. Chien C. (2003) Cheap Drugs at What Price to Innovation: Does the Compulsory Licensing of Pharmaceuticals Hurt Innovation? Berkeley Technology Law Journal, no. 3. pp. 853-907.

4. Di Masi J.A., Grabowski H.G. (2007) The cost of biopharmaceutical R\&D: is biotech different? Managerial and Decision Economics, vol. 28, no. 4-5, pp. 469-479. DOI: 10.1002/mde.1360

5. Di Masi J.A., Hansen R.W., Grabowski H.G. (2003) The Price of Innovation: New Estimates of Drug Development Costs. Journal of Health Economics, vol. 22, no. 2, pp. 151-185

6. Digital Health Trends 2021: Innovation, Evidence, Regulation, and Adoption. IQVIA 2021. Available at: https://www.iqvia.com/-/media/ iqvia/pdfs/institute-reports/digital-health-trends-2021/iqvia-institutedigital-health-trends-2021.pdf (accessed: 02.09.2021)

7. Dutfield G. (2003) Intellectual property rights and the life science industries: A twentieth century history. L.: Routledge, $304 \mathrm{p}$.

8. Impact of rapid technological change on sustainable development (2019) Report of the Secretary-General. Economic and Social Council. Commission on Science and Technology for Development. E / CN.16 / 2019/2. 17 p.

9. Khabriev R., Abashidze A., Malichenko V. (2016) The role of pharmaceutical regulation in implementation of the human right to the highest attainable standard of health. Zhurnal zarubezhnogo zakonodatel'stva $i$ sravnitel'nogo pravovedeniya = Journal of Foreign Legislation and Comparative Law, no. 2, pp. 16-22. (In Russ.).

10. Mukherjee S. (2017) Emerging infectious diseases: Epidemiological perspective. Indian Journal of Dermatology, vol. 5, pp. 459-467.

11. National Health Security Strategy 2019-2022 (2018) 24 p. Available at: https://www.phe.gov/Preparedness/planning/authority/nhss/Documents/NHSS-Strategy-508.pdf (accessed: 31.08.2021) 
12. Rehabilitation in health systems (2017) Geneva: World Health Organization, p. 35. Available at: https://www.wipo.int/edocs/pubdocs/en/ wipo_pub_gc_20.pdf (accessed: 22.02.2021)

13. Schweitzer S.O., Lu Z.J. (2018) Pharmaceutical economics and policy: perspectives, promises and problems. Oxford: University Press. $352 \mathrm{p}$.

14. Wirtz V.J., Hogerzeil H.V. et al. (2017) Essential medicines for universal health coverage. The Lancet, no. 389, pp. 403-476.

\section{Information about the author:}

V.S. Malichenko - Candidate of Sciences (Law), Senior Researcher.

The article was submitted 20.09.2021; approved after reviewing 11.10.2021; accepted for publication 01.11.2021. 